\title{
Anxiety, Motivation and Autonomy in Iranian High School Students: A Quantitative Study
}

\author{
Fatemeh Sanadgol \\ English Department, Science and Research Branch, Islamic Azad University, Gorgan, Iran \\ Seyed Jalal Abdolmanafi-Rokni (Corresponding author) \\ English Department, Golestan University, Gorgan, Iran \\ E-mail: j.abdolmanafi@gmail.com
}

Doi:10.7575/aiac.alls.v.6n.1p.143

Received: 18/09/2014

URL: http://dx.doi.org/10.7575/aiac.alls.v.6n.1p.143

Accepted: 03/12/2014

\begin{abstract}
Research in the series of second language learning certify that both cognitive and affective factors within a language learner affect the level of success that will be achieved in learning a second language. This study was an attempt to investigate the relationship among three factors of anxiety, motivation, and autonomy. To this purpose, 207 students were invited from Golestan high school in Ramian, in the north of Iran. Their age ranged from 18 to 22 years. In one session they filled out the anxiety questionnaire, in the next session they completed the motivation questionnaire, and in the third session they answered the items in the autonomy questionnaire. At the end of the term their final scores were recorded. Analysis of the results showed that there was a meaningful relationship between anxiety and motivation, but there was no relationship between anxiety and autonomy, and no relationship autonomy and motivation. Both highstakeholders and low-stakeholder may benefit from the findings of this study.
\end{abstract}

Keywords: motivation; anxiety; autonomy; EFL learners

\section{Introduction}

Research in the series of second language learning certify that both cognitive and affective factors within a language learner affect the level of success that will be get in learning a second language (L2). Earlier research concentrated on finding out the effect of cognitive factors on language learning, but since the 1960s, there have been more studies on finding out the effect of affective factors, such as motivation and anxiety (Gardner, 1985). Affective factors are defined as "those that deal with the emotional response and motivations of the learner" (Scovel, 1978, 131).

There has been a good progression of literature in the series of English language admonition dealing with the psychological position of learning, such as motivation and anxiety. Many researchers have observed that both motivation (Clement et al., 1994; Dornyei, 2001; Mehrpour \& Vojdani, 2012) and anxiety (Horwitz et al., 1986; MacIntyre \& Gardner, 1989; Liu \& Jackson, 2008) are important factors in second and foreign language learning.

For the past three decades, motivation has been a great area for experiential research and scientific work within the context of learning mother tongue, foreign language, and second language. Motivation indicates one of the most pleasant variables used to demonstrate the differences in learners during language learning (Pintrich \& Schunk, 2002), and it is also one of the most serious factors that accelerate the pace and success of language learning (Dornyei, 1998).

Foreign language anxiety is convenient ever more substantial in second language proprietorship studies. Commonly, anxiety is looked to be achy to manufacture on learning tasks that require attention (Roccas \& Brewer, 2002). Horwitz, Horwitz, and Cope (1986) defined anxiety as a "subjective feeling of tension, apprehension, nervousness, and worry" (p.125). An investigation directed on foreign language anxiety has expressed that anxiety forbids language learners from gaining a higher level of skill in foreign languages and it is negatively related to foreign language learning (Aida, 1994). Several studies (e.g., Brown, Robson, \& Rosenkjar, 2001; Gardner, Masgoret, Tennant, \& Mihic, 2004; Hao, Liu, \& Hao, 2004) have explored motivation and language anxiety, but there have been some studies on the direct relationship between the two affective factors.

As represented above, both anxiety and motivation play a fundamental part in English learning. In addition, they are closely related to each other in second and foreign language inception (Liu \& Huang, 2011). Further, various levels of foreign language learners' accomplishment might be influenced by anxiety and motivation. It is thus important to seek the relationship between motivation and anxiety in terms of students' English learning achievement (Hao, Liu, \& Hao, 2004).

In the series of school education, such as high schools and university, much research has been conducted on motivation and anxiety in Iranian English learners. But the research on motivation and anxiety of English learners in technical high school in Iran is totally limited. Given the context that high schools have been developing and the need for their students learning English has been increasing. Since the purpose of this study is to help specify how and to what extent 
foreign language learning anxiety and motivation interplay and influence English language learning performances among high school students in Iran.

On the other side, learner autonomy and taking engagement for one's own learning processes has become a central concern in the recent history of language teaching (Holec, 1981; Dickinson, 1987; Little, 2009). Ways of creating autonomy or motivating the idea of autonomy in language classrooms are not easy to reach (Dickinson, 1992; Nunan, 1997; Littlewood, 1997). Promoting learner autonomy is to encourage students "to determine the objectives, to define the contents and progressions, to select methods and techniques to be used, to monitor the procedures of acquisition and to evaluate what has been acquired" (Holec, 1981, p.3). Through this process, eventually, the autonomous learner establishes "a personal agenda for learning" (Little, 1994; Chan, 2003) by setting up track in the planning, pacing, monitoring and evaluating the learning process.

Learner autonomy is firmly on the opinion that if students are involved in intent making processes regarding their own language competence, "they are likely to be more focused and purposeful for them (Little, 1991; Chan, 2003). Additionally, the concept that "learners have the power and right to learn for themselves" (Smith, 2008, p. 2) is seen as an essential aspect for learner autonomy.

There is document in research studies to support the claim that "increasing the level of learner control will increase the level of self-determination, thereby increasing overall motivation in the improvement of learner autonomy" (Chan, 2001, p. 506). Thus, in order to contribute to the improvement of learner autonomy in language classrooms, it is fundamental that students be complex in making intent about their own learning.

There is an important role for teachers in this process since "the ability to behave autonomously for students is dependent upon their teacher creating classroom culture where autonomy is accepted" (Barfield et al., 2001, p. 3). It is unreal to anticipate teachers to develop an impression of autonomy but they have themselves experienced teacher training, where an exploratory and evaluative approach to learning and teaching have been key elements (Little, 1995; Castle, 2006; Burkert \& Schwienhorst, 2008). De Vries and Kohlberg (1987) give a picture of what an autonomous teacher looks like.

"The autonomous constructivist teacher knows not only what to do, but why. She has a solid network of convictions that are both practical and theoretical. The autonomous teacher can think about how children are thinking and at the same time think about how to interact to increase the constructive culture. Autonomous teachers do not just accept uncritically what curriculum specialists give them. They think about whether they agree with what is suggested. They take responsibility for the education they are offering children" (p. 380).

Language teachers without any autonomy-partial training may experience difficulties in creating such a classroom culture. Hence, the earlier language teachers who are in support of the principles of autonomous learning are made aware of the importance and demand of learner autonomy in their initial teacher training, the more easily they will be able to implement this approach in their own future classrooms.

Likewise, Little (1995), McGrath (2000), Smith (2000), Huang (2005), Sert (2006), Viera (2007), Smith and Erdojan (2007) and Burkert and Schwienhorst (2008) provide evidence that teachers who themselves are not autonomous language learners may have a negative influence on the development of autonomy in their students.

According to Little (1995, p. 175), learner autonomy depends on teacher autonomy in two senses. It is unreasonable to expect teachers to foster the growth of autonomy in their learners if they themselves do not know what it is to be an autonomous learner. In determining the initiatives they take in their classrooms, teachers must be able to apply to their teaching those same purposeful and self-managing processes that they apply to their learning (p. 175).

On this fundament, teachers need to experience autonomous skills in their initial teacher training, so they will be able to take a positive PLACE about the EXTENTION of learner autonomy in their own teaching and their students can take charge of their own learning following the models of their teachers. Working on learner autonomy in language learning focuses not only on out-of-class learning (Benson, 2001), but also classroom practice (Dam, 1995; Little, 1991). As mentioned above, language teachers have a vital role to play in fostering learner autonomy by taking both out-of-class and classroom outlook. Thus, if our target enthusiastic about learning" (Littlejohn, 1985, p. 258) and learning can be more, it is to lead our student teachers to become autonomous teachers, an understanding of student teachers' perspectives on learner autonomy while they are being trained to be teachers would provide valuable information for teacher educators.

\subsection{Research Questions}

This study employed only quantitative data. Accordingly, the research questions are as follows:

RQ1. To what extent, if any, is there a correlation between the participants' levels of anxiety and motivation?

RQ2. To what extent, if any, is there a correlation between the participants' levels of motivation and autonomy?

RQ3. To what extent, if any, is there a correlation among the participants' levels of anxiety and autonomy?

\section{Methodology}

\subsection{Participants}

This study was conducted at Golestan high school in Ramiyan, in the north of Iran. The 207 participants were studying at high school during 2013 academic years; there were female and male students. All the participants were high school students ranging in age from 18 to 22 years. A summary of the relevant demographic information of the participants in this study is provided in Table 1. 
Table 1. Relevant demography of students (total $\mathrm{N}=207$ )

\begin{tabular}{lll}
\hline Gender & Number of students & Percentage \\
\hline Female students & 127 & $61 \%$ \\
\hline Male students & 80 & $39 \%$ \\
\hline Age & & \\
\hline between $18-22$ & 207 & $100 \%$ \\
\hline
\end{tabular}

\subsection{Instruments}

\section{Foreign Language Classroom Anxiety Scale (FLCAS)}

The questionnaire used to scale the levels of anxiety in foreign language learners was the Foreign Language Classroom Anxiety Scale (FLCAS), developed by Horwitz, Horwitz, and Cope in 1986. The FLCAS is a 33-item instrument that distinguish the degree to which students feel anxious during language classes by distinguishing their correlation apprehension, test anxiety, and fear of negative evaluation in the foreign language classroom. Each item is an expression followed by a five-point Likert response scale, with which the participants indicate the degree to which they agree or disagree with each of the items. Items on this scale are both positively and negatively worded. The total possible score ranges from 33 to 165 , with the higher scores indicating higher levels of foreign language anxiety. Validity and reliability of previous studies have shown that the scale is both valid and reliable (Horwitz et al., 1986) with an alpha coefficient of 0.93 and an eight-week test-retest coefficient of .83. Also, Aida's (1994) study of 96 students in a second-year Japanese course used the same instrument and reported a Cronbach's alpha coefficient of .94. Alpha coefficient ranges in value from 0 to 1 and shows how well a set of items measure a single unidimensional construct. The higher the score, the more reliable the generated scale is. A reliability coefficient of .70 is considered as "acceptable" in the literature. To determine if the anxiety experienced by the participants in this study was state anxiety rather than trait anxiety, seven extra Likert response questions were added to the 33-item FLCAS, making it a 40-item questionnaire. These items were adapted from the General Anxiety Scale Items by Spielberger (1972), and comprise numbers 34 to 40 on the questionnaire. The validity and reliability scores of the FLCAS were not altered because the scores obtained on the seven additional questions were computed separately. As was noted above, the data from these additional items resulted in the elimination of two students from the study.

\section{Attitude/Motivation Test Battery (AMTB)}

The questionnaire used to measure levels of motivation was the modified Attitude/Motivation Test Battery (AMTB), originally developed by Gardner (1985) and revised by Gardner, Tremblay and Masgoret in 1997. This instrument investigate such factors as state toward learning English, wish to learn English, and motivational intensity in learning English. Like the FLCAS, each item here is in addition followed by a five-point Likert response scale for participants to display the degree to which they agree or disagree with the statements. Again, some of the items on this scale are also both positively and negatively worded. Validity and reliability of previous studies have shown that the scale is both valid and reliable, with coefficients of .91 and .89 respectively, and a six-week test-retest coefficient of .79 .

\section{Questionnaire on Autonomy}

The students' levels of autonomy in learning English were determined by using the questionnaire formulated by Spratt, Humphreys and Chan (2002). This questionnaire was strongly influenced by Holec's (1981) definition of autonomy, and the researchers attempted to incorporate the notions of "ability" and "responsibility" in the five areas of their questionnaire, which aims to assess students' readiness for learner autonomy in language learning by examining their views of their responsibilities and those of their teachers, their confidence in their ability to operate autonomously. It also investigated their actual practice of autonomous learning in the form of both outside and inside class activities. The terms "Not at all", "A little", "Some", "Mainly" or "Completely" were used on the five-point Likert response scale in this questionnaire. This questionnaire on autonomy was collected, piloted, amended and then administered to 207 participants, third grade of high school 2013.

\subsection{Procedure}

Permission was obtained from the high school to conduct this study. Permit was also obtained from the educator of the two second-term English course to visit their classes to collect the data. One of the researchers set the time and plan for data collection to the educator, and asked for time in class to manage three questionnaires on anxiety motivation, and autonomy. Then, the researcher met the classes two days before the performance of the first instrument to recommend the term-long project to the students and enroll their help. They were not told that the affective factors of anxiety, motivation, and autonomy were being researched. The participants were certain that their information would remain confidential and that their intention to participate (or not) would not affect their class grade, and were then asked to sign an agreement form. This caution was taken not only because the school rules require it but also with the attempt of making the students feel convenient with the whole procedure, to give them an opportunity to ask any questions, and to detract any anxiety that could be caused by having to deal with the unexpected.

During week 5 of the term, the three instruments which were questionnaires on anxiety, motivation, and autonomy were administered to the students. Data were collected during week 5 , and not earlier in the term, because it was hoped that 
by this time the students would have had an opportunity to defeat any initial trouble and anxiety they might have experienced due to being in a new class with new classmates and instructor. It was hoped that any anxiety they felt during week 5 would be directly related to their language learning experiences in general, as opposed to specific newsemester factors.

\subsection{Data Analysis}

The research questions were answered quantitatively by using statistical tests to evaluate the significance of the collected data. Research questions of the present study aimed at finding out the correlations between the participants' levels of anxiety, motivation, and autonomy. The Spearman signed-rank correlation test was run on the scores the participants obtained on the questionnaires measuring anxiety, motivation, and autonomy to determine if there were any correlations among these variables.

\section{Results}

With regard to the first research question, "To what extent, if any, is there a correlation between the participants' levels of anxiety and motivation?", since the data gathered through the two questionnaires of anxiety and motivation is ordinal (in Likert scale format), the appropriate test for correlation would be the Spearman rank-order correlation. Table 2 below shows the result of the Spearman rank-order correlation.

Table 2. Result of the Spearman rank-order correlation

\begin{tabular}{lllll}
\hline & & ANXIETY & MOTIVATION \\
\hline Spearman's rho & ANXIETY & Correlation Coefficient & 1.000 & $.260^{* *}$ \\
& Sig. (2-tailed) &. & .000 \\
& $\mathrm{~N}$ & 207 & 207 \\
\cline { 2 - 5 } MOTIVATION & Correlation Coefficient & $.260^{* *}$ & 1.000 \\
& Sig. (2-tailed) & .000 &. \\
& $\mathrm{~N}$ & 207 & 207 \\
\hline
\end{tabular}

**. Correlation is significant at the 0.01 level (2-tailed).

A Spearman's Rank Order correlation was run to determine the relationship between anxiety and motivation. There was a small, positive correlation between these two variables, which was statistically significant $\left(r_{s}(205)=.260, p=.000\right)$.

With regard to the second research question, "To what extent, if any, is there a correlation between the participants' levels of motivation and autonomy?", since the data gathered through the two questionnaires of motivation and autonomy is ordinal (in Likert scale format), the appropriate test for correlation would be the Spearman rank-order correlation. Table 3 below shows the result of the Spearman rank-order correlation.

Table 3. Result of the Spearman rank-order correlation for motivation and autonomy

\begin{tabular}{lllll}
\hline & & MOTIVATION & AUTONOMY \\
\hline Spearman's rho & MOTIVATION & Correlation & 1.000 & .012 \\
& & Coefficient & & .864 \\
& Sig. (2-tailed) &. & 207 \\
\cline { 2 - 5 } & $\mathrm{N}$ & 207 & 1.000 \\
& Correlation & .012 &. \\
& Coefficient & & 207 \\
& Sig. (2-tailed) & .864 & 207 & 207 \\
\hline
\end{tabular}

A Spearman's Rank Order correlation was run to determine the relationship between motivation and autonomy. There was a very small positive correlation between these two variables, which was not statistically significant $\left(r_{s}(205)=.012\right.$, $p=.864)$. With the mentioned correlation coefficient, nothing can be judged based on statistics.

With regards to the third research question, "To what extent, if any, is there a correlation among the participants' levels of anxiety and autonomy?", the Spearman rank-order correlation was used. Table 4 below shows the result of the Spearman rank-order correlation. 
Table 4. Result of the Spearman rank-order correlation for motivation and autonomy

\begin{tabular}{lllll}
\hline & & ANXIETY & AUTONOMY \\
\hline Spearman's rho & ANXIETY & Correlation Coefficient & 1.000 & -.094 \\
& Sig. (2-tailed) &. & .177 \\
& $\mathrm{~N}$ & 207 & 207 \\
\cline { 2 - 5 } & AUTONOMY & Correlation Coefficient & -.094 & 1.000 \\
& Sig. (2-tailed) & .177 &. \\
& $\mathrm{~N}$ & 207 & 207 \\
\hline
\end{tabular}

The Spearman's Rank Order correlation was run to determine the relationship between anxiety and autonomy. There was a very small negative correlation between these two variables, which was expectedly not statistically significant $\left(r_{s}(205)=-.094, p=.177\right)$. Therefore, it can be stated that these two variables are negatively correlated.

\section{Discussion and Conclusion}

Considering the first research question, anxiety and motivation seem to be two interacting factors. The presence of one does not exclude the existence of another. MacIntyre (1995) believes that high levels of anxiety have a negative effect on the performance of language learners, while moderate levels of anxiety can be useful by motivating students to work harder to reach their goals.

The present results are contrary to those of Gardner, Day, and MacIntyre (1992), who examined the effects of both motivation and anxiety on computerized vocabulary acquisition and proposed that anxiety and motivation are correlated yet distinguishable.

Concerning the second research question, Dornyei $(1994,2001)$ believes that a motivated class has more autonomy since they are less dependent on the teacher. They can perform better on the tasks and exercises they receive; however, teachers have a great responsibility in providing help for the students to maintain their motivation.

The results of the third research question were similar to the findings of Shinge (2005) where no significant relationship was found between anxiety and autonomy.

\subsection{Pedagogical Implications}

The results showed that there was a small positive correlation between the levels of anxiety and motivation experienced by the participants in this survey, showing to some extent that anxious students can be motivated. Students in any classroom have different characters and respond to position in various ways. Teachers of English should consider this point to take advantage of different individuals. Thus, teachers should not give up on their anxious students fearless that anxious students are likely to be less motivated to learn. Given this knowledge, educators can adjust their works to motivating students and also reducing their anxiety. When educators realize that a student who is willing and motivated in completing class work or engaging in class activities can also experience anxiety, which could plain itself in any form, such as feelings of adversity or inefficacy, they may use anxiety-reducing manner to teach those students.

No correlation was found between the anxiety and autonomy levels in the participants. There was a very small negative correlation between these two variables, which was expectedly not statistically significant. These results suggest that educators should not consider that their anxiety-ridden students cannot take accountability of their learning and show signs of being autonomous.

Similarly, teachers need to be aware that autonomous students who seem to have taken charge of their own learning may still feel worried (though it was not proven here in this research) about their foreign language learning experiment, which in period, could affect their class grades. For example, students may be worried about whether the target and plans they have set up for their own study will be effective or not. Even if there are students who seemingly do not require help from the teachers, the teacher should still be supportive towards them.

As to the motivation and autonomy, there was a very small positive correlation between these two variables, which was not statistically significant. Though autonomous students are expected to be more motivated in their study, such a conclusion was not drawn here.

\subsection{Suggestions for Further Research}

It would be attractive to again conduct this study with not only a different group of students learning English but also with students learning other languages to notice if similar results are obtained considering the correlation among different variables, especially those included in this research.

The data in this study were collected over a period of eight weeks, shorter or longer periods are suggested in order to find out the possible changes related to the course of time.

This study portrays a preliminary effort to examine the correlation among three variables of anxiety, motivation, and autonomy. Other variables such as willingness to communicate, stress, belief, and locus of control are suggested to be investigated in future research. 
It is recommended that this study be replicated with a larger sample or number of participants from the same background.

The present study may be replicated having participants from lower or upper levels.

It would be interesting to compare the results across levels of proficiency among non-English students at university level.

It is recommended that a treatment as an independent variable be worked out with students and its possible effect be investigated on the three variables mentioned above.

These suggested chains of research might shed more light on second language acquisition involving any variable affecting language learning. They should inform us as to which combinations of strategies or techniques will enhance L2 learning the most. Lastly, it is hoped that the outcome of this study be of some help to future research studies, both for teachers and learners of English.

\section{References}

Aida, Y. (1994). Examination of Horwitz, Horwitz, and Cope's construct of foreign language anxiety: The case of students of Japanese. Modern Language Journal, 78(2), 155-168.

Barfield, A., Ashwell, T., Carroll, M., Collins, K., Cowie, N., Critchley, M., Head, E., Nix, M., Obermeier, A. \& Robertson, M.C. (2001). Exploring and defining teacher autonomy: A collaborative discussion. In A. S. Mackenzie \& E. McCafferty (Eds.), Developing Autonomy, Proceedings of the College and University Educators' 2001 Conference, Shizuoka, Japan (pp. 217-22). Tokyo: The Japan Association for Language Teaching.

Benson, P. (2001). Teaching and researching autonomy in language learning. Harlow: Longman.

Brown, J., Robson, G., \& Rosenkjar, P.R. (2001). Personality, motivation, anxiety, strategies, and language proficiency of Japanese students. In Z. Dornyei \& R. Schmidt (Eds.), Motivation and second language acquisition (pp. 361-398). Honolulu, HI: University of Hawai'i Press.

Burkert, A. \& Schwienhorst, K. (2008). Focus on the Student Teacher: The European Portfolio for Student Teachers of Languages (EPOSTL) as a Tool to Develop Teacher Autonomy. Innovation in Language Learning and Teaching, 2(3), 238- 252.

Castle, K. (2006). Autonomy through Pedagogical Research. Teaching and Teacher Education, 22(8), $1094-1103$.

Chan, V. (2001). Readiness for learner autonomy: What do our learners tell us? Teaching in Higher Education, 6(4), 505-519.

Chan, V. (2003). Autonomous Language Learning: the teachers' perspectives. Teaching In Higher Education, 8(1), 3354.

Clement, R., Dornyei, Z., \& Noels, K.A. (1994). Motivation, self-confidence, and group cohesion in the foreign language classroom. Language Learning, 44(3), 417-448.

Dam, L. (1995). Learner Autonomy 3: from theory to classroom practice. Dublin: Authentik.

De Vries, R. \& Kohlberg, L. (1987). Programs of early education. New York: Longman.

Dickinson, L. (1987). Self-instruction in Language Learning. Cambridge: Cambridge University Press.

Dickinson, L. (1992). Learning Autonomy 2: learner training for language learning. Dublin: Authentik.

Dornyei, Z. (1994). Motivation and motivating in the foreign language classroom. Modern Language Journal, 78(3), 273-284.

Dornyei, Z. (1998). Motivation in second and foreign language learning. Language Teaching, 31, 117-135.

Dornyei, Z. (2001). New themes and approaches in second language motivation research. Annual Review of Applied Linguistics, 21, 43-59.

Gardner, R.C. (1985). Social psychology and second-language learning: The role of attitudes and motivation. London, England: Edward Arnold.

Gardner, R.C., Day, J.B., \& MacIntyre, P.D. (1992). Integrative motivation, induced anxiety, and language learning in a controlled environment. Studies in Second Language Acquisition, 14, 197-214.

Gardner, R.C., Masgoret, A.M., Tennant, J., \& Mihic, L, (2004). Integrative motivation: Changes during a year-long intermediate-level language course. Language Learning, 54, 1-34.

Gardner, R.C., Tremblay, P.F., \& Masgoret, A.M. (1997). Towards a full model of second language learning: An empirical investigation. The Modern Language Journal, 81(iii), 344-362.

Hao, M., Liu, M., \& Hao, R. P. (2004). An empirical study on anxiety and motivation in English as a foreign language. Asian Journal of English Language Teaching, 14, 89-104.

Holec, H. (1981). Autonomy in foreign language learning. Oxford: Pergamon. 
Horwitz, E.K., Horwitz, M.B., \& Cope, J. (1986). Foreign language classroom anxiety. Modern Language Journal, 70, 125-132.

Huang, H. (2005). Current teaching approaches in Taiwanese English classrooms and recommendations for the future. Unpublished doctoral dissertation. Claremont Graduate University, Claremont, CA.

Little, D. (1991). Learner autonomy 1: Definitions, issues and problems. Dublin: Authentik.

Little, D. (1994). Learner autonomy: A theoretical construct and its practical application. Die Neuere Sprache, 93(5), 430-442.

Little, D. (1995). Learning as dialogue: The dependence of learner autonomy on teacher autonomy. System, 23(2), 175182.

Little, D. (2009). Language learner autonomy and the European Language Portfolio: Two L2 English examples. Language Teaching, 42, 222-233.

Littlejohn, A. (1985). Learner choice in language study. ELT Journal, 39(4), 253-261.

Liu, M. \& Huang, W. (2011). An exploration of foreign language anxiety and English learning motivation, Educational Research International, 1-8, doi:10.1155/2011/493167.

Liu, M. \& Jackson, J. (2008). An exploration of Chinese EFL learners' unwillingness to communicate and foreign language anxiety. The Modern Language Journal, 92(1), 71-86.

MacIntyre, P.D. (1995). How does anxiety affect second language learning? A reply to Sparks and Ganschow. Modern Language Journal, 79(1), 90-99.

MacIntyre, P.D., \& Gardner, R.C. (1989). Anxiety and second-language learning: Toward a theoretical clarification. Language Learning, 39(2), 251-275.

McGrath, I. (2000). Teacher autonomy. In B. Sinclair, et al. (Eds.), Learner autonomy, teacher autonomy: Future directions (pp. 100-110). London: Longman.

Mehrpour, S. \& Vojdani, M. (2012). Globalization and EFL learning motivation: A new perspective on integrative vs. instrumental motivation among Iranian learners of English. Open Journal of Modern Linguistics, 2, 43-50, doi: 10.4236/ojml.2012.22006.

Nunan, D. (1997). Designing and adapting materials to encourage learner autonomy. In P. Benson \& P. Voller (Eds.), Autonomy and independence in language learning (pp. 192-203). London: Longman.

Pintrich, P.R. \& Schunk, D.H. (2002). Motivation in education: Theory, research, and application (2nd ed.). New Jersey: Merrill Prentice Hall.

Roccas, S. \& Brewer, M. (2002). Social identity complexity. Personality and Social Psychology Review, 6, 88-106.

Scovel, T. (1978). The effect of affect on foreign language learning: A review of the anxiety research. Language Learning, 28(1), 129-142.

Sert, N. (2006). EFL Student Teachers' Learning Autonomy. The Asian EFL Journal, 8(2), 180-201.

Shinge, M. (2005). Interplay among anxiety, motivation, and autonomy in second language learners of French: a quantitative and qualitative study. Unpublished doctoral dissertation. University of Florida.

Smith, R.C. (2000). Starting with ourselves: Teacher-learner autonomy in language learning. In B. Sinclair, et al. (Eds.), Learner autonomy, teacher autonomy: Future directions (pp. 89-99). London: Longman.

Smith, R.C. (2008). Learner autonomy (Key concepts in ELT). ELT Journal, 62(4), 395-397.

Smith, R.C. \& Erdogan, S. (2007). Teacher-learner autonomy: Programme goals and student teacher constructs. In T. Lamb \& H. Reinders, (Eds). Learner and Teacher Autonomy: Concepts, Realities and Responses (pp. 83-103). Amsterdam: Benjamins.

Spielberger, C.D. (1972). Anxiety: Current trends in theory and research: I. New York, N.Y.: Academic Press.

Spratt, M., Humphreys, G., \& Chan, V. (2002). Autonomy and motivation: Which comes first? Language Teaching Research, 6(3), 245-266.

Viera, F. (2007). Teacher Autonomy: Why should we care? Independence 40 (IATEFL Learner Autonomy SIG). 